\title{
Total Quality Management Practices In Boosting Performance of Corporate Hospitals - A Study
}

\author{
SYEDA AMTUL MAHABOOB
}

Department of Management and Commerce, Maulana Azad National Urdu University, Telangana.

\begin{abstract}
The Healthcare industry is on its boom in the city of Hyderabad. People not only from various cities of India but also from foreign countries come to Hyderabad for their medical treatment. There are various corporate Hospitals in the city catering to the needs of the people. The management of the Corporate Hospitals being very keen about delivering quality services is maintaining a quality department. Total Quality Management Practices are adopted as one of the ways to ensure quality. The present study is conducted in five Corporate Hospitals of the city to know whether Total Quality Management Practices has any effect on the Organizational Performance of the Hospitals. The data was collected in the form of responses from nurses, doctors, supporting and admin staff of the Hospitals by stratified random sampling method. It was found that there is a positive influence of the total quality management practices on the performance of the Hospitals.
\end{abstract}

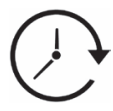

Article History

Received: 10 April 2021

Accepted: 18 May 2021

\section{Keywords}

Healthcare;

Hyderabad;

Management Practices;

quality;

Total Qualit.

\section{Introduction}

There is a great potential in the industry of Healthcare. It accounts to be one the world's largest revenue generating industry of US $2.8 \$$ Trillion approximately. Indian Healthcare has emerged to be one of the largest service sectors of the country contributing to five percent in India's GDP and four million people being offered jobs in the industry. Twelve percent of expansion has been experienced by the sector over the last four years according to the Investment Commission of India. Six to seven percent of India's GDP is expected to be contributed by the sector and will offer jobs to more 2.5 million people as per the reports of Cll-McKinsey (Venkat Ramana 2012).

There has been an increasing awareness in the customers of the Healthcare industry i.e., the patients about quality and it is being highly recognized by the management of the Hospitals that delivering quality services is the only way of sustaining in the national as well as international market.

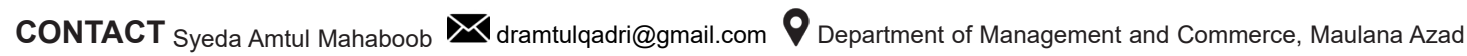
National Urdu University, Telangana.

\section{(c) (i)}

(c) 2021 The Author(s). Published by Enviro Research Publishers.

This is an Open Access article licensed under a Creative Commons license: Attribution 4.0 International (CC-BY).

Doi: http://dx.doi.org/10.12944/JBSFM.02.01.09 
Vol. 02(1 \& 2) 78-88 (2021)

The rising literacy rate, higher levels of income and media creating deeper awareness about quality has led the Indian shopper quicker to claim eminent services in Healthcare. Such pointers have not only been the part of the cause of the development of Healthcare sector in India but also making themoves towards the Accreditation (Venkat Ramana 2012).

Accreditation is a set of standards to promote quality improvement regulated either by the government or private agencies. The management of the Hospitals applies to the accreditation bodies periodically once or twice in a year to get certified that they maintain quality services in their Organization. This also enables them to show it to their customers that a certification has been obtained and the services of the Hospital can be completely relied upon.

In Indian scenario NABH (National Accreditation Board of Health) is the certifying body which provides accreditation to the Hospitals. Almost every Corporate Hospital is accredited by NABH (National Accreditation Board of Health) and maintains a quality department.

Total Quality Management has emerged as one of the useful tools in delivering services with quality to the patients in the Healthcare Sector. Though their use started first in manufacturing industry but later they were adopted in the services industry like Healthcare and Education.

TQM is explained as a management tactic which endeavors to achieve and prolong long term firm's performance by inciting personnel ratings and involvement, gratifying consumer requirements and suppositions, paying equal importance to morals and ethics of the community, tuning with the laws of the government (Poornima M.Charantimath 2013).

The present study utilizes an award model called MBNQA to recognize the foremost TQM Dimensions. MBNQA (Malcolm Baldrige National Quality Award) Model is a criterion given via National Institute of Standards and Technology and this award is given annually by the institution to recognize the manufacturing and service industries (including Healthcare) that excel in their services.

MBNQA (Malcolm Baldrige National Quality Award) Model identifies the following TQM Practices and links them with the performance of the Organization (NIST 2018).

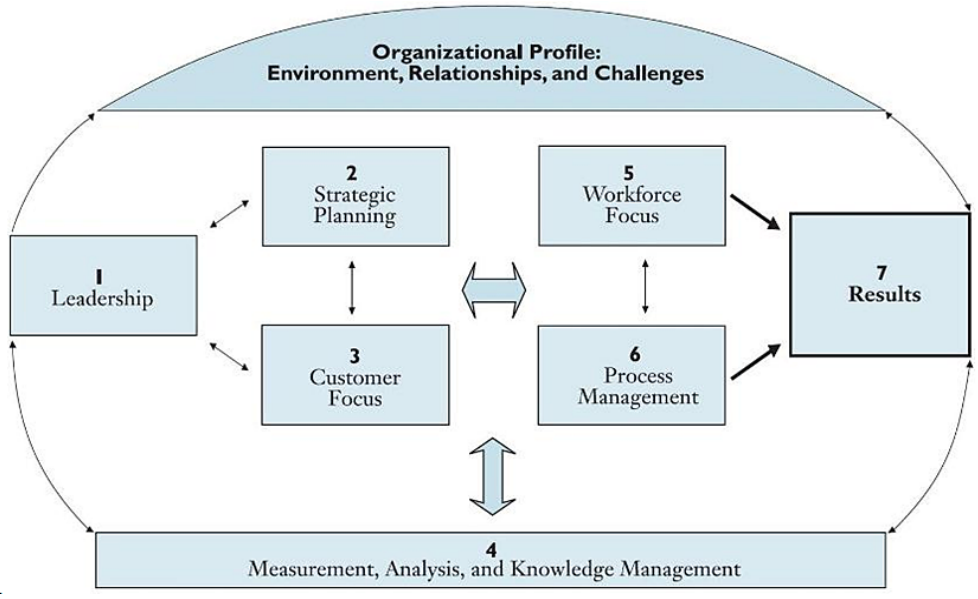

Fig.1: MBNQA (Malcolm Baldrige National Quality Award Model)

SOURCE: Total Quality Management by K. ShridharaBhat (2011) Himalaya Publishing House

The TQM Practices highlighted by MBNQA can be listed as:

- Leadership

- $\quad$ Strategic Planning
- Customer Focus

- Measurement, Analysis and Knowledge Management.

- Workforce Focus

- Operations Management (Processes) 
It is being recognized by several researchers that TQM practices can act as an effective tool to improve the performance of the Hospitals. In order to get an understanding that whether the TQM practices has an influence on the performance of the Hospitals; the present research has been conducted. The present study tests the influence of these TQM Dimensions shown by MBNQA model on the Performance of five selected private Hospitals of Hyderabad city.

\section{Research Question}

The following is the research question of the Study:

- Is there any influence of TQM Dimensions on the Performance of five private Hospitals of Hyderabad city?

\section{Research Objective}

The following is the objective of the research:

- To study the influence of TQM Dimensions on the Performance of the hospitals.

\section{Review of Literature}

The research on Total Quality Management in Hospitals has not been discussed until the late nineteenth century (Goldstein \& Schweikhart 2002).

Most of the researchers who did their research on TQM in Healthcare industry utilized the MBNQA (Malcolm Baldrige National Quality Award) Model (Manjunath Usha 2007).

Lin and Clousing (1995) conducted a study of thirty one hospitals in United States and discovered that most of the hospitals follow TQM and bring an improvement in the key performance areas of the Hospital.

Wilson and Collier (2000) performed a study in hospitals of America and a found a positive relationship between TQM practices and Organizational Performance.

Meyer and Collier (2001) verified the associations in Malcolm structure using the data from two hundred and twenty US hospitals and concluded that the causal relationships in the Baldrige criteria are statistically significant.

Goldstein \& Schweikhart (2002) collected the data from two hundred and twenty American Healthcare institutions and examined associations among the
MBNQA criterion for Medical institutions of TQM and performance of these Hospitals.

R. Rohini (2006) performed a study in Hospitals of Karnataka to check the influence of TQM Practices on the performance of these medical organizations using SERVQUAL and MBNQA Model.

Alexander, Weiner, \& Griffith (2006) examined the relationship between the Quality improvement (QI) implementation in one thousand seven hundred and eighty four hospitals and Organizational Performance. The results suggested that QI (Quality Improvement) had a defined impression on global procedures of medical institution's performance and the ways to Quality Improvement affect in these areas.

Manjunath Usha (2007) performed a study throughout India to evaluate the efficiency of TQM Practices in bringing about a change in performance of the Hospitals.

Fereshteh Farzianpour et al (2011)evaluated the performance of a medical teaching institution federated to an Iranian University of Medical Sciences based on Malcolm standard structure. The implementation was assessed by dual queries which were based on process category and result category. The outcomes of the study pointed that the Malcolm framework acts as a strongest technique to evaluate excellence assessment of the Iranian medical institutions.

Apinan Aueaungkul (2013) collected the perceptions of the respondents from eighty four hospitals and forty three educational institutional of Thailand. The exploration scrutinized the level of TQM adoption in hospital and universities, underlined the critical success factors and gathered data to elucidate the impact of Thai cultural practices on TQM adoption. $\mathrm{He}$ also insisted the eminence of Malcolm structure in enhancing performance of medical institutions.

Sang M. Lee, Don Hee Lee and David L. Olson (2013) explored 254 Korean medical institutions for evaluating association of the seven categories of Malcolm structure and results of the institutions. They utilized various quantitative approaches, evaluated their assumption depending on the information gathered from two hundred and fifty four 
Vol. 02(1 \& 2) 78-88 (2021)

medical institutions. The outputs of the research indicated that the different elements of healthcare procedures are highly related with every element of Malcolm structure in the hospital firm.

Salaheldin Ismail Salaheldin (2015) carried out a research to explore the function ofimprovement on the Dimensions of total quality managing execution in the hospitals of Jordan.

Beatrice Dinda et al (2016) adopted co relational survey research in hospitals of Nairobi. The research elaborated those procedures of excellence (Data Analysis, Process Administration, encouragement of senior executives) were important indicators of firm performance. Excellence maintenance procedures were found to be great indicators of medical institution's attainment in corporate Nairobian medical institutions. Procedures of excellence had an influence on hospital performance.

The present study also aims at connecting with the results of the previous researches and finding the link between the total quality management practices and performance of the hospitals.

\section{Research Methodology}

\section{Sources of Data Collection (primary)}

Opinions of the administration staff, physicians, nurses and supporting workforce concerning different Dimensions of TQM and Hospital execution were collected through a tested and adopted structured questionnaire for the primary data.The data obtained is continuous in nature.

\section{Questionnaire}

A tested structured questionnaire by Manjunath (2007) was used to collect the responses of the hospital staff regarding each of the TQM practices using a five point likert scale ranging from Strongly Agree to Strongly Disagree and for Organizational Performance, a five point likert scale ranging from very low to very high. The questionnaire had already been tested by Manjunath (2007) for all the TQM Dimensions of MBNQA Criterion.

\section{Sources of Secondary Data}

Secondary data for the study was collected from various online and published journals, thesis, books and internet websites. The secondary data collected for the study contained various studies showing the association of TQM practices with the performance of the healthcare organizations.

- The Study is Descriptive in nature and the data collected is tested in an analytical manner.

\section{Population}

Five corporate hospitals of the city namely Premier hospital, Olive hospital, Virinchi hospital, Care hospital and Apollo hospital were chosen for the study. Total number of employees of the five hospitals is 3445 .

\section{Sampling Unit}

346 Employees from five corporate hospitals which include administrative staff, physicians, nurses and supporting staff. The sample size confirms with the Krejcie and Morgan's table. Krejcie and Morgan (1970) in their article "Determining Sample Size for Research Activities" gave a table for determining the sample size for various populations. Thus the sample taken in this study validates with the Krejcie and Morgan's table.

\section{Sampling Method}

Stratified Random Sampling method was used. Hospital staff is divided into four strata namely administrative staff, doctors, nurses and supporting staff.

- $\quad$ Ten percent of the employees are taken from each stratum. All the primary data measured in continuous scale assuming the values on the scale are equi-distant.

\section{Sampling Frame}

\section{Hypothesis}

The hypothesis of the study is follows:

- $\mathrm{H}_{01}$ : There is no statistically significant influence of TQM Dimensions on Hospital's Performance.

- $\mathrm{H}_{1}$ : There is a statistically significant influence of TQM Dimensions on Hospital's Performance.

\section{Data Analysis and Interpretation}

To test the influence of TQM Dimensions on Performance of five private Hospitals, Simple Linear Regression has been used. 
MAHABOOB, Journal of Business Strategy, Finance and Management,

Vol. 02(1 \& 2) 78-88 (2021)

Table 1: Sampling Frame

\begin{tabular}{lcccccc}
\hline Hospital & Doctors & Nurses & $\begin{array}{c}\text { Administrative } \\
\text { Staff }\end{array}$ & $\begin{array}{c}\text { Supporting } \\
\text { Staff }\end{array}$ & Total \\
\hline PREMIER & 5 & 10 & 5 & 25 & 45 \\
OLIVE & 6 & 12 & 5 & 27 & 50 \\
CARE & 8 & 17 & 5 & 40 & 70 \\
VIRINCHI & 8 & 20 & 6 & 47 & 81 \\
APOLLO & 9 & 16 & 6 & 69 & 100 \\
\hline
\end{tabular}

Overall total no of employees selected $=346$.

The influence of each TQM Dimension on the Hospital Performance is checked by taking each practice alone as an independent variable and Organizational Performance as a dependent variable.
Conceptual Framework of the Research Independent Variables

TQM practices from MBNQA model were regarded as independent variables.

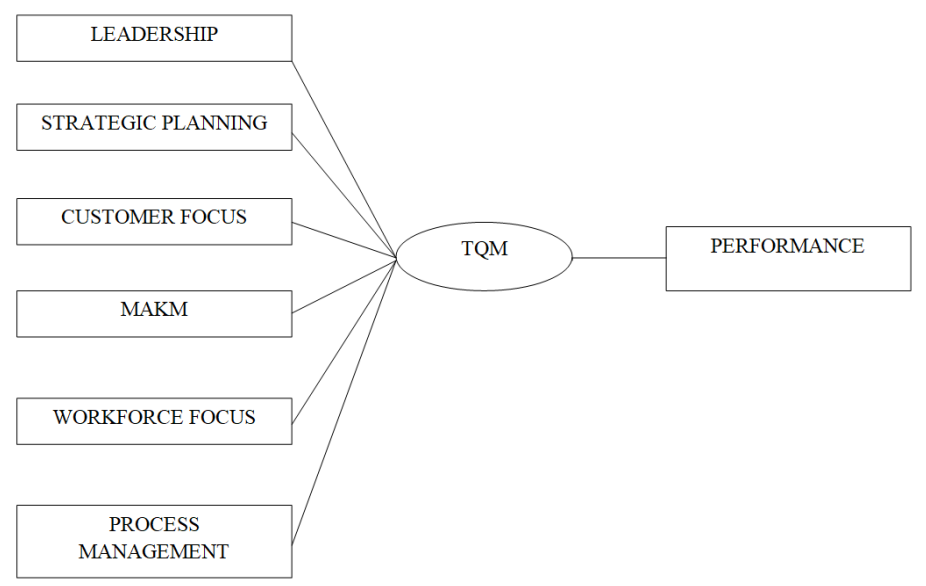

Fig. 2: Conceptual Model of the study

Dependent Variable

Performance of the hospital was regarded as a dependent variable.

The above figure depicts the conceptual framework of the study with TQM practices as independent variables and the performance of the hospital considered dependent.

\section{Statistical Analysis}

Simple Linear Regression Analysis forexamining the influence of Leadership on Hospitals Performance:

Table 2: Model Summary

\begin{tabular}{ccccc}
\hline Model & $\mathbf{R}$ & R Square & Adjusted R Square & Std. Error of the Estimate \\
\hline 1 & 0.614 & 0.377 & 0.375 & 3.20303 \\
\hline
\end{tabular}


Vol. 02(1 \& 2) 78-88 (2021)

Table 3: Anova Table

\begin{tabular}{cccccc}
\hline Model & Sum of Squares & df & Mean Square & F & Sig \\
\hline $\begin{array}{ccccc}\text { 1Regression } \\
\text { Residual }\end{array}$ & 2136.916 & 1 & $\begin{array}{c}2136.916 \\
10.259\end{array}$ & 208.289 & 0.000 \\
\hline
\end{tabular}

Table 4: Coefficients Table

\begin{tabular}{lcccc}
\hline Model & UnstdCoeff B & StdCoeff Beta & t & Sig \\
\hline Constant & 12.141 & & 7.449 & 0.000 \\
Leadership & 0.918 & 0.614 & 14.432 & 0.000 \\
\hline
\end{tabular}

Dependent Variable: Organizational Performance

Independent Variable: Leadership

The regression correlation coefficient, $R$, is simply the Pearson correlation coefficient between the scores predicted by the regression model (i.e., the predicted scores) and the actual values of the dependent variable. In this model, $\mathrm{R}$ is a measure of the strength of the linear association between these two variables and can give an indication as to the goodness of the model fit with a value that can range from 0 to 1 , with higher values indicating a stronger linear association. Table 2 shows the R Square alue of 0.377 i.e., thirty seven percent change, moderate lefgel of change in the Performance can be predicted by the Leadership and the Coefficient Table 4 confirms to the Regression Coefficient for Leadership is the change in the dependent variable Organizational performance for one unit change in the independent variable occupational stress. For one unit of increase of Leadership 0.918 units of performance will be effected. If we consider standardized coefficients a beta value of 0.614 indicates that a change of one standard deviation in the independent variable Leader ship results in a 0.382 standard deviations Organizational performance will be effected.

Simple Linear Regression Analysis for examining influence of Strategic Planning on the Hospitals Performance

Table 5: Model Summary

\begin{tabular}{ccccccc}
\hline Model & R & R Square & Adjusted R Square & Std. Error of the Estimate \\
\hline 1 & 0.471 & 0.222 & 0.220 & 3.57957 \\
\hline \multicolumn{7}{c}{ Table 6: Anova Table } \\
\hline Model & Sum of Squares & df & Mean Square & F & Sig \\
\hline $\begin{array}{l}\text { Regression } \\
\text { Residual }\end{array}$ & $\begin{array}{c}1258.371 \\
4407.779\end{array}$ & $\begin{array}{c}1 \\
344\end{array}$ & $\begin{array}{c}1258.371 \\
12.813\end{array}$ & 98.208 & 0.000 \\
\hline
\end{tabular}

Similarly, Table 5 shows the R Square (regression) value of 0.222 i.e., twenty two percent change in the Performance can be predicted by the Strategic
Planning and the Coefficient table 7 displays us the Regression Coefficient for Strategic Planning is 0.484 . 
MAHABOOB, Journal of Business Strategy, Finance and Management,

Vol. 02(1 \& 2) 78-88 (2021)

Table 7: Coefficients Table

\begin{tabular}{lcccc}
\hline Model & UnstdCoeff B & StdCoeff Beta & $\mathbf{t}$ & Sig \\
\hline Constant & 19.200 & & 11.571 & 0.000 \\
Strategic Planning & 0.484 & 0.471 & 9.910 & 0.000 \\
\hline
\end{tabular}

Dependent Variable: Organizational Performance

Independent Variable: Strategic Planning

Simple Linear Regression Analysis for examining influence of Customer Focus on the Hospitals Performance:

Table 8 shows the R Square (regression) value of 0.070 i.e., a certain variation in the Performance that can be predicted through Customer Focus and the Coefficient table 10 shows that the Regression Coefficient for Customer Focus is $\mathbf{0 . 4 4 5 .}$

Simple Linear Regression Analysis for examining influence of Measurement, Analysis plus Knowledge Management onthe Hospitals Performance

Table 8: Model Summary

\begin{tabular}{ccccc}
\hline Model & $\mathbf{R}$ & R Square & Adjusted R Square & Std. Error of the Estimate \\
\hline 1 & 0.264 & 0.070 & 0.067 & 3.91443 \\
\hline
\end{tabular}

Table 9: Anova Table

\begin{tabular}{|c|c|c|c|c|c|}
\hline Model & Sum of Squares & df & Mean Square & $\mathbf{F}$ & Sig \\
\hline Regression & 395.120 & 1 & 395.120 & 25.786 & 0.000 \\
\hline Residual & 5271.030 & 344 & 15.323 & & \\
\hline
\end{tabular}

Table 10: Coefficients Table

\begin{tabular}{lcccc}
\hline Model & Unstd Coeff B & Std Coeff Beta & t & \multicolumn{1}{c}{ Sig } \\
\hline R Constant & 26.042 & & 13.847 & 0.000 \\
Customer Focus & 0.445 & 0.264 & 5.078 & 0.000 \\
\hline
\end{tabular}

Dependent Variable: Organizational Performance

Independent Variable: Customer Focus

Table 11: Model Summary

\begin{tabular}{ccccc}
\hline Model & $\mathbf{R}$ & R Square & Adjusted R Square & Std. Error of the Estimate \\
\hline 1 & 0.434 & 0.189 & 0.186 & 3.65598 \\
\hline
\end{tabular}


Vol. 02(1 \& 2) 78-88 (2021)

Table 12: Anova Table

\begin{tabular}{lccccc}
\hline Model & Sum of Squares & df & Mean Square & F & Sig \\
\hline Regression & 1068.192 & 1 & $\begin{array}{c}1068.192 \\
13.366\end{array}$ & 79.918 & 0.000 \\
Residual & 4597.959 & 344 & & \\
\hline
\end{tabular}

Table 13: Coefficients Table

\begin{tabular}{lcccc}
\hline Model & Unstd Coeff B & Std Coeff Beta & $\mathbf{t}$ & \multicolumn{2}{c}{ Sig } \\
\hline Constant & 15.915 & & 7.224 & 0.000 \\
MAKM & 0.521 & 0.434 & 8.940 & 0.000 \\
\hline
\end{tabular}

Dependent Variable: Organizational Performance

Independent Variable: Measurement, Analysis and Knowledge

Management

Table 11 shows the $\mathrm{R}$ Square (regression) value of 0.189 i.e., a certain variation in the Organizational Performance that can be predicted through the Measurement, Analysis and Knowledge Management. The Coefficient table 13 displays us the Regression Coefficient is 0.521 .

Simple Linear Regression Analysis for examining influence of Workforce Focus towards the Hospitals Performance
Table 14 shows the $\mathrm{R}$ Square (regression) value of 0.230 i.e., twenty three percent variation in the Organizational Performance that can be predicted through Workforce Focus. The Coefficient table 16 displays us the Regression Coefficient is 0.361 .

Simple Linear Regression Analysis for examining how Process Management has an influenceon the Hospitals Performance

Table 14: Model Summary

\begin{tabular}{|c|c|c|c|c|c|c|c|}
\hline Model & $\mathbf{R}$ & R Square & \multicolumn{2}{|c|}{ Adjusted R Square } & \multicolumn{3}{|c|}{ Std. Error of the Estimate } \\
\hline 1 & 0.479 & 0.230 & \multicolumn{2}{|c|}{0.228} & \multicolumn{3}{|c|}{3.56154} \\
\hline \multicolumn{8}{|c|}{ Table 15: Anova Table } \\
\hline \multicolumn{2}{|c|}{ Model } & Sum of Squares & df & \multicolumn{2}{|c|}{ Mean Square } & $\mathbf{F}$ & Sig \\
\hline \multicolumn{2}{|c|}{ Regression } & 1302.650 & 1 & \multicolumn{2}{|c|}{1302.650} & 102.695 & 0.000 \\
\hline \multicolumn{2}{|c|}{ Residual } & 4363.500 & 344 & \multicolumn{2}{|c|}{12.685} & & \\
\hline
\end{tabular}

Table 16: Coefficients Table

\begin{tabular}{lcccc}
\hline Model & Unstd Coeff B & Std Coeff Beta & t & \multicolumn{1}{l}{ Sig } \\
\hline Constant & 17.973 & & 10.311 & 0.000 \\
& Workforce Focus0.361 & 0.479 & 10.134 & 0.000 \\
\hline
\end{tabular}

Dependent Variable: Organizational Performance Independent Variable: Workforce Focus 
Table 17 shows the $R$ Square (regression) value of 0.369 i.e., thirty six percent variation in the Performance that can be predicted through Process
Management. The Coefficient table 19 shows that the Regression Coefficient is 1.006 .

Table 17: Model Summary

\begin{tabular}{ccccc}
\hline Model & R & R Square & Adjusted R Square & Std. Error of them Estimate \\
\hline 1 & 0.607 & 0.369 & 0.367 & 3.22500 \\
\hline
\end{tabular}

Table 18: Anova Table

\begin{tabular}{lccccc}
\hline Model & Sum of Squares & df & Mean Square & F & Sig \\
\hline Regression & 2088.331 & 1 & $\begin{array}{c}2088.331 \\
10.401\end{array}$ & 200.789 & 0.000 \\
Residual & 3577.819 & 344 & 10.00 & \\
\hline
\end{tabular}

Table 19: Coefficients Table

\begin{tabular}{lcccc}
\hline Model & Unstd Coeff B & Std Coeff Beta & t & Sig \\
\hline Constant & 9.723 & 5.314 & 0.000 & \\
Process Management & 1.006 & 0.607 & 14.170 & 0.000 \\
\hline
\end{tabular}

Dependent Variable: Organizational Performance

Independent Variable: Process Management

From the above analysis we deduce that a positive influence of TQM Dimensions on the Performance of the five Corporate Hospitals is present.

Therefore we discard the null hypothesis and agree to the alternate hypothesis which affirms that there is a major influence of TQM Dimensions on the Hospitals Performance.

\section{Findings}

It can be deduced from the analysis of the simple linear regression analysis tables that every TQM practice had a positive influence on the Hospital performance. The coefficients tables showed a significant positive connection of each TQM Dimension with the performance.Therefore it can be said that TQM Practices acts as useful tool in improving the Performance of the selected private Hospitals of Hyderabad.

\section{Constraints}

There were two constraints of the research:

- The research focused on the TQM adoption only in selected corporate hospitals and hence the results need not apply to all the hospitals in the country.

- This study covers only corporate hospitals but not the public hospitals.

\section{Conclusion}

The present study was conducted with an objective of finding whether TQM Dimensions can boost Performance of the Hospitals in Hyderabad. The previous studies done on showing an association of Total Quality Management Dimensions with performance of the healthcare institutions found a positive result. Hence by observing the results of the previous studies, it was decided to test an association 
Vol. 02(1 \& 2) 78-88 (2021)

of the TQM Dimensions with the performance of the Hospitals in Hyderabad city. The data collected on TQM dimensions and performance were tested to know whether there exists an influence of the independent variable on the dependent by the tool of regression. The positive influence was observed from the statistical analysis of regression. The results of the present research connected well with the results of the previous studies and gave the same association.

It is concluded that TQM Practices acts an effective tool in improving the Organizational Performance of the Hospitals and they should be applied if a Hospital wants to boost its performance. The conclusion of the study however is limited to selected hospitals. The study can cover Public Hospitals of the city in future to know if TQM is being followed in these Hospitals too and whether they are efficient enough in improving the Organizational Performance of these Hospitals.

\section{Acknowledgement}

I would like to thank the Department of Management and Commerce, Maulana Azad National Urdu University, Hyderabad for allowing me to do my PhD during the year 2016-2019. The present research paper is a part of my PhD research work. I would also like to thank the department of statistics, Osmania University, Hyderabad for the statistical analysis of the collected data.

\section{Funding}

There is no funding or financial assistance provided for conducting this research work.

\section{Conflict of Interest}

The author does not have any conflict of interest with anyone.

\section{References}

1. Alexander, Jeffrey A.; Weiner, Bryan J.; Griffith, John. (2006) "Quality improvement and hospital financial performance". Journal of Organizational Behavior, 27(7),1003-1029.

2. Aueaungkul, Apinan. (2013) "An investigation of Critical Success Factors

3. and Thai cultural impact". Doctor of Philosophy thesis, School of Information Systems and Technology, University of Wollongong. http:// ro.uow.edu.au/theses/3899

4. Beatrice Dinda, Dr. Patrick B.Ojera and Dr. BulitiaGodrick Mathews. (2016)"Analysis of Quality Management Practices and Organizational Performance of Private Healthcare Facilities in Nairobi County, Kenya". International Journal of Novel Research in Marketing Management and Economics, 3(3), 115-125.

5. Fereshteh Farzianpour, Sara Aghababa, Bahram Delgoshaei and Marjan Haghgoo. (2011)“Performance Evaluation a Teaching Hospital Affiliated to Tehran University of Medical Sciences Based on Baldrige Excellence Model". American Journal of Economics and Business Administration, 3(2), 272-276.

6. Goldstein, S., \& Schweikhart, S. (2002)“Empirical support for the Baldrige award framework in U.S.hospitals". Health Care Management Review, 27(1), 62-75.

7. G. V.R.K. Acharyulu and V. Venkat Ramana. Emerging Trends in Healthcare and Hospital Management(1 ${ }^{\text {st }}$ Ed), India: Paramount Publishing House;2012.

8. K. Shridhara Bhat..Total Quality Management $\left(1^{\text {st }} \mathrm{Ed}\right)$, India: Himalaya Publishing House;2011.

9. Krejcie and Morgan. (1970). "Determining Sample size for research activities". Educational and Psychological Measurement, 30, 607-610.

10. Lin, B., \& Clousing, J. (1995). "Total quality management in healthcare: A survey of current practices". Total Quality Management, 6(1), 69-78.

11. Lee, S., Lee, D. and Olson, D. (2013). "Healthcare quality management using the MBHCP excellence model". Total Quality Management \& Business Excellence, 24(1-2), 119-137.

12. Meyer, S., \& Collier, D. (2001). "An empirical test of the causal relationships in the Baldrige health care pilot criteria". Journal of Operations Management, 19(4), 403-425.

13. Manjunath $U$, Metri BA, Ramachandran S. (2007). "Quality management in health care 
organization: a case of South Indian Hospital". TQM Magazine, 19(2), 129-139.

14. ManjunathUsha.(2007). "Development of an Integrative Framework for Total Quality Service in Hospitals-An Empirical Investigation". Doctor of Philosophy thesis, BITS Pilani.http://hdl. handle.net/10603/124553

15. Poornima M. Charantimath.Total Quality Management ( $2^{\text {nd }}$ Ed), India: Pearson Education; 2013.

16. R. Rohini.(2006). "TQM practices in healthcare services- An Empirical study". Doctor of Philosophy thesis, University of Mysore.http:// hdl.handle.net/10603/92272

17. Salaheldin Ismail Salaheldin, SamiaFathi and Mohammad S. Shawaheen.(2015). "Critical Success Factors for Total Quality Management Implementation in Jordanian Healthcare Sector". European Scientific Journal, 11(13), 153-162.

18. Wilson, D.D., Collier, D.A.(2000). "An empirical investigation ofthe Malcolm Baldrige National Quality Award causal model".Decision Sciences, 31 (2), 361-390.

19. Websites:

20. Baldrige Criteria for Healthcare. https://www. nist.gov/baldrige/about-baldrige-excellenceframework-health-care. Accessed on $30^{\text {th }}$ March 2018. 